\title{
A FIRST STUDY ON THE ZOOPLANKTON- CYANOBACTERIA INTERACTIONS IN KARAOUN RESERVOIR (LEBANON) DURING 2016-2017
}

\author{
Kamal Slim ${ }^{1}$ and Ali Fadel ${ }^{* 2}$ \\ ${ }^{1}$ Laboratory of Microorganisms and Food Irradiation, Lebanese Atomic Energy \\ Commission-CNRS, P.O. Box 11-8281, Riad El Solh, Beirut 1107 2260, Lebanon. \\ ${ }^{2}$ National Center for Remote Sensing, National Council for Scientific Research, P.O. \\ Box 11-8281, Riad El Solh, Beirut 1107 2260, Lebanon. \\ *Corresponding author: Ali Fadel \\ afadel@cnrs.edu.lb
}

(Received May 2018 - Accepted May 2019)

\begin{abstract}
Slim, K. and Fadel, A. 2019. A first study on the zooplankton-cyanobacteria interactions in Karaoun reservoir (Lebanon) during 2016-2017. Lebanese Science Journal. 20(2): 248-261.

The planktonic organisms are characterized by their strong capacity of reproduction as well as a high death rate. The factors that intervene simultaneously and result in the seasonal succession and change in the planktonic community are not well studied, especially in Middle East fresh water bodies. Stratification, nutrients, oxygen and light intensity can lead to an increase in phytoplankton and cyanobacteria biomass. In this study, we monitor the interaction between zooplankton and cyanobacteria in Karaoun Reservoir, the largest freshwater body in Lebanon. Karaoun Reservoir has gone through a degradation of its water quality and eutrophication with a very low phytoplankton biodiversity and a dominance of two toxic cyanobacteria species (Microcystis aeruginosa and Aphanizomenon ovalisporum) forming a thick bloom that persisted during the years 2016 and 2017. This spring bloom assured the development of small cladoceran, rotifers that were replaced progressively by big cladoceran such as Daphnia and by copepods Calanoides. Having strongly contributed to the exhaustion of their food resources and being equally submitted to a strong predation from the zooplankton feeding fish such as the carps, the zooplanktonic species decrease gradually till their total disappearance at the beginning of summer. The lake's zooplankton does not proliferate until the end of spring and disappears completely after. The environment rich in cyanotoxins does not seem to be responsible for this decrease. This was attributed to the grazing by Cyprinus carpio. The cycle of these


species pass through a period of spring reproduction which allows the zooplankton to develop without being reduced by these fish species.

Keywords: zooplankton; cyanobacteria, freshwater, grazing.

\section{INTRODUCTION}

Plankton constitutes the base of food chain in aquatic ecosystems. They occur both in Freshwater and marine ecosystems and consist of phytoplankton and zooplankton communities (El Hourany et al., 2017). Toxic cyanobacteria are harmful group of phytoplankton communities (Fadel et al., 2014). Cyanobacterial blooms are globally widespread and constitute a threat to the ecological health of many eutrophic systems (Chorus and Bartram, 1999; Fadel, 2014; Temsah et al., 2016). Anthropogenic activities and land degradation (Darwish et al., 2018; Darwish and Fadel, 2017) together with climate change presented by rises in temperature are believed to promote harmful algal blooms (Paerl, 2008; Slim et al., 2014). Blooming of cyanobacteria such as Microcystis aeruginosa, Anabaena, Cylindrospermopsis, Planktothrix, Aphanizomenon and Nodularia dominate the phytoplankton community and disturb food web processes due to their high abundance, high toxicity and poor food quality for grazers (Paerl and Huisman, 2009). Zooplanktons consume phytoplankton and play important role in transferring carbon and energy to upper trophic levels in the food web. Therefore, the interaction between phytoplankton and zooplankton, especially the relationship between cyanobacteria and zooplankton, has gathered increasing attention (Griffin et al., 2001).

Microcystis is one of the most common and most studied bloom-forming cyanobacteria and a well-known producer of the hepatotoxic microcystins (Gumbo et al., 2008; Latour et al., 2007; Vinçon-Leite et al., 2017). Different cladocerans usually exhibited different responses to the toxicity of Microcystis (Gołdyn and KowalczewskaMadura, 2008; Work and Havens, 2003; Yang et al., 2006), and usually small-sized cladocerans exhibit higher tolerance to toxic Microcystis in field. Similar tolerance to toxic Microcystis was found in different species of cladocerans, regardless of herbivore body size in laboratory experiments. It remains unknown why the field and laboratory experiments contradict one another. A long-time exposure of Daphnia to cyanobacteria may enhance their resistance to the cyanobacteria. Aphanizomenon seems rarely to be toxic to zooplankton. Using Daphnia, no toxic effect was found (Lampert, 1981).

Meanwhile, phytoplankton community has been studied in Karaoun Reservoir (Fadel et al., 2019), there are no or very little studies have been made on the interaction between phytoplankton communities and zooplankton in the Middle East region and in Karaoun Reservoir (Fadel et al., 2015). Hence, in this work, we try to monitor the occurrence and dynamics of both phytoplankton and zooplankton community in Karaoun Reservoir to increase the understanding of the interaction between these plankton communities that constitute the base of the food chain in aquatic ecosystems. 


\section{MATERIALS AND METHODS}

\section{Study site}

Lake Karaoun, located in the southern part of the Bekaa plain, is the largest artificial freshwater body in Lebanon (Figure 1). The lake was constructed between 1958 and 1965 along Litani River (170km length). It has a maximum capacity of $230.10^{6} \mathrm{~m}^{3}$. The lake is located in a semiarid climate, characterized by a moderately cold winter season and distinctly dry and hot summer. The annual precipitation rate in the lake area is about $800 \mathrm{~mm}$. The heaviest rainfall period is between November and April. However, the lake area is characterized with little or no precipitation between June and September. The lake serves various purposes such as: hydropower generation, fisheries and aquaculture, recreational activities, tourism, and irrigation through canal 900 (Fadel et al., 2017).

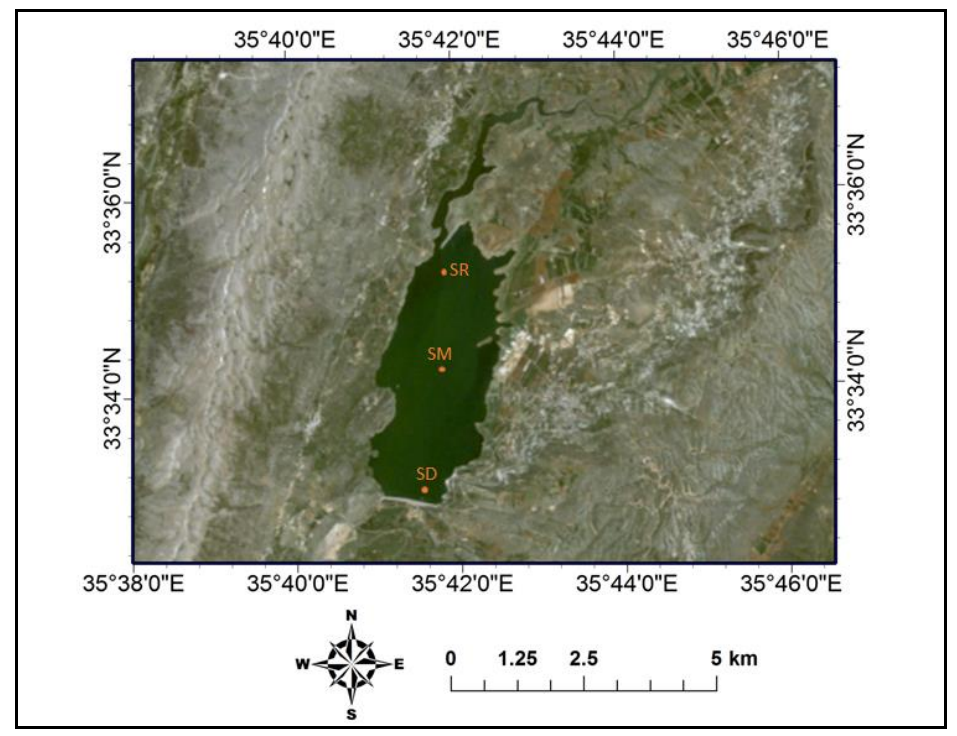

Figure 1. Lake Karaoun and sampling sites.

In the last decade, the lake changed from an oligotrophic to hypertrophic state (Fadel et al., 2016). Solid waste dumping, animal-raising farm, industrial wastes, food processing plants, and other polluting activities on upper Litani river basin that supply Lake Karaoun has increased its trophic level (Fadel and Slim, 2018; Mcheik et al., 2018). In summer 2016, the canal 900 used for irrigation by water taken from the hypolimion of Karaoun Reservoir was closed because of its bad odor (rich in $\mathrm{CH}_{4}$, ammonium and $\mathrm{H}_{2} \mathrm{~S}$ ).

\section{Plankton samples}

Water samples were taken monthly, between 11:00 and 12:00 h during the study period, at the most representative point (SM), in the middle of the lake (Figure 1). Water 
samples were collected by lowering the polyethylene bottles to about $0.5 \mathrm{~m}$ beneath the water level and stored at $4^{\circ} \mathrm{C}$ until further processing in the laboratory.

Phytoplankton and zooplankton samples were harvested with a plankton net (20 $\mu \mathrm{m}$ mesh size) at the top $10 \mathrm{~m}$ depth and fixed with formaldehyde at a $5 \%(\mathrm{v} / \mathrm{v})$ final concentration.

They were then determined in the same day according to taxonomic keys based on cell structure and dimensions, colony morphology, and mucilage characteristics (Komárek and Anagnostidis, 2005, 1999). Microscopic identifications and enumeration of both phytoplankton and zooplankton were carried out under a phase contrast microscope (Nikon TE200, Nikon, Melville, New York, USA).

\section{Water temperature}

Water temperature was measured at different depth each hour using Hobo sensors.

\section{RESULT AND DISCUSSION}

\section{Zooplankton community identified between 2015 and 2017}

Table 1 presents the zooplankton species that were identified in Karaoun Reservoir between 2015 and 2017. It shows the occurrence of 4 predator functional groups $(\mathrm{P}), 5$ microzooplankton grazors $(\mathrm{Mi})$ and 9 macrozooplankton grazers $(\mathrm{Ma})$. The size of the different taxonomic group was between 102 and $360 \mu \mathrm{m}$ for Copepoda, between 119 and $2500 \mu \mathrm{m}$ for Cladocera and between 212 and $620 \mu \mathrm{m}$ for Rotifera.

Table 1. List of zooplankton categories in Karaoun during 2015-2017.Functional group: predatory (P), macrozooplankton grazers (Ma) and microzooplankton grazers (Mi).

\begin{tabular}{|l|c|c|c|}
\hline \multicolumn{1}{|c|}{ Species } & $\begin{array}{c}\text { Taxonomic } \\
\text { Grouping }\end{array}$ & $\begin{array}{c}\text { Functional } \\
\text { Group }\end{array}$ & $\begin{array}{c}\text { Mean length } \\
(\boldsymbol{\mu m})\end{array}$ \\
\hline Cyclops sp & Copepoda & $\mathrm{Mi}$ & 102 \\
\hline Eudiaptomus gracilis & Copepoda & $\mathrm{p}$ & 360 \\
\hline Mesocyclops ogunnus & Copepoda & $\mathrm{Ma}$ & 316 \\
\hline Thermocyclops dybowski & Copepoda & $\mathrm{P}$ & 313 \\
\hline Diaphanosoma brachyurum & Cladocera & $\mathrm{Ma}$ & 331.7 \\
\hline Bosmina longirostris & Cladocera & $\mathrm{Ma}$ & 272.1 \\
\hline Ceriodaphnia reticulata & Cladocera & $\mathrm{Ma}$ & 873 \\
\hline Chydorus sphaericus & Cladocera & $\mathrm{Ma}$ & 119 \\
\hline Leptodora kindtii & Cladocera & $\mathrm{Ma}$ & 620 \\
\hline Daphnia longirostris & Cladocera & $\mathrm{Ma}$ & 2500 \\
\hline Daphnia magna & Cladocera & $\mathrm{Ma}$ & 642 \\
\hline Graptolebris testudinari & Cladocera & $\mathrm{Ma}$ & 240 \\
\hline
\end{tabular}




\begin{tabular}{|l|l|l|l|}
\hline Asplanchna brightwelli & Rotifera & $\mathrm{P}$ & 414 \\
\hline Asplanchna priodonta & Rotifera & $\mathrm{P}$ & 612 \\
\hline Brachionus calyciflorus & Rotifera & $\mathrm{Mi}$ & 519 \\
\hline Hexathra intermedia & Rotifera & $\mathrm{Mi}$ & 620 \\
\hline Keratella cochlearis & Rotifera & $\mathrm{Mi}$ & 202 \\
\hline Trichocera stylata & Rotifera & $\mathrm{Mi}$ & 212 \\
\hline
\end{tabular}

First study performed on zooplankton was in the end of the nineteenth century. It was done by Theodore Barrois in 1890 on the geographical distribution of Cladocera in Palestine, Syria and Egypt. Lebanon was mentioned as well in that study, noting on the possibility of its existence in some hydrostatics present at that time: Yammouneh Lake, Orontes's swamps, Baalbek's planes, and Beirut road. The number of collected species in the research in Lebanon turned out to be around twelve species where five of these species were collected as well in Karaoun Lake $(*)$ :

- $\quad$ Diaphonosoma brachyurum (*)

- Daphnia longispina (*)

- $\quad$ Simocephalus vetulus (*)

- $\quad$ Moina rectirostris

- Ceriodaphnia rotunda

- Bosmina cornuta

- B. longirostris (*)

- Camptocereus sp.

- Leydigia acanthocereoides

- $\quad$ Alona intermedia

- $\quad$ Pleuroxus trigonellus

- $\quad$ Chydorus sphaericus (*)

\section{Cyanobacterial succession}

Karaoun dam was subject to major changes in it phytoplankton community during the last 20 years. Before the year 2000, Karaoun dam was dominated by diatoms which represented about $80 \%$ of the total phytoplankton count (Slim, 1996). Karaoun dam had a high phytoplankton biodiversity. More than 90 species were identified between in 2000-2001, among which about sixty species of planktonic diatoms, between 2002 and 2003, filamentous green algae dominated the reservoir (Fadel, 2014).

Toxic cyanobacterial blooms of two major species, Aphanizomenon ovalisporum and Microcystis aeruginosa (M. aeruginosa) were first reported in 2009. Since then, these two cyanobacterial species together with other phytoplankton species dominate the lake with a predictable and similar blooming pattern each year. Aphanizomenon ovalisporum (A. ovalisporum) is mostly seen at the beginning of spring and autumn while $M$. aeruginosa is seen in summer. A. ovalisporum optimal temperature is smaller than that of $M$. aeruginosa allowing it to dominate in spring and autumn. 
In freshwater bodies around the world, $M$. aeruginosa grows best at a temperature range between 28 and $32{ }^{\circ} \mathrm{C}$ and has a minimal growth temperature of 20 ${ }^{\circ} \mathrm{C}$ (Imai et al., 2009; Robarts and Zohary, 1987). Although A. ovalisporum is a nitrogen-fixing bacterium, capable of providing its own nitrogen sources by fixing atmospheric nitrogen, it is outcompeted by M. aeruginosa in Lake Karaoun whenever water temperature reaches above $25^{\circ} \mathrm{C}$.

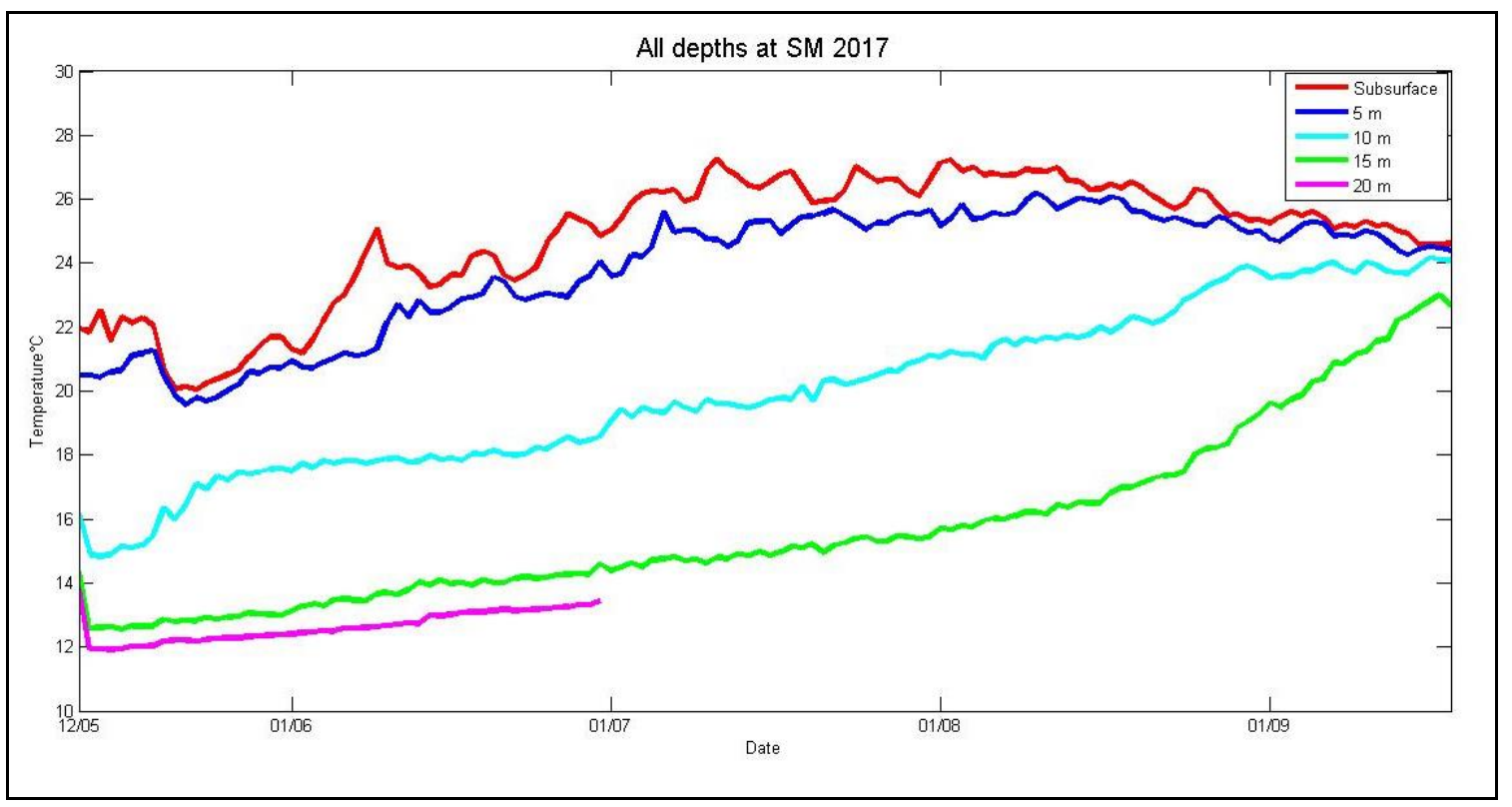

Figure 2. Water temperatures at different depths in 2017 at Karaoun Reservoir.

Species diversity is greatly reduced during the blooms of $M$. aeruginosa and A. ovalisporum. When they bloom in Lake Karaoun they constitute more than $95 \%$ of the total phytoplankton biomass with minor occurrence of two or three species. In October 2017, M. aeruginosa and A. ovalisporum disappear suddenly and the phytoplankton is occupied by $M$. wesenbergii (95\%).

Factors underlying during late summer 2017 bloom of $M$. wesenbergii in Karaoun dam remain speculative. Many prerequisites have been suggested, including unusually warm temperatures and calm winds, elevated concentrations of nutrients (especially $\mathrm{P}$, but also trace metals and other growth factors), and recent changes in hydrological regimes Karaoun dam. Though present ever since, the bloom of $M$. wesenbergii in October 2017 and complete disappearance of $M$. aeruginosa and $A$. ovalisporum, is more bewildering. Clearly, changes at the ecosystem level are involved, as anthropogenic stress in Karaoun dam has increased continually throughout recent decade. Unfortunately, the number of possible factors, and the complexity with which these factors could interact to provide $M$. wesenbergii with the opportunity to invade Karaoun dam, severely reduce the possibility of ever pinpointing an exact cause of the bloom. 


\section{Cyanobacteria-Zooplankton abundance: interactions}

Numerous studies have found correlations between the abundance of zooplankton grazers and the timing of cyanobacterial blooms. These studies suggest grazing by large zooplankton with zooplankton promotes high densities of colonies of cyanobacteria, presumably through the elimination of smaller, more easily grazed phytoplankton that are competitors for an essential resource such as nutrients or light. In eutrophic reservoirs and carp ponds the development of blooms of Aphanizomenon was consistently associated with the presence of the large cladoceran Daphnia sp.

With respect to grazing, cyanobacteria have been shown to be poor quality food for most zooplankton, with most studies focusing on Daphnia (Tillmanns et al., 2008; Wilson et al., 2006). Numerous laboratory studies have also demonstrated that cyanobacteria can inhibit Daphnia feeding, growth, survival, and reproduction, and the production of toxic secondary metabolites has been hypothesized to mediate these negative effects (DeMott William et al., 2018; Lampert, 1981; Sommer et al., 2012). Therefore, an important effect of cyanobacterial dominance with nutrient enrichment is that phytoplankton communities tend to be dominated by harmful species that are relatively resistant to zooplankton grazing (Sommer et al., 1986).

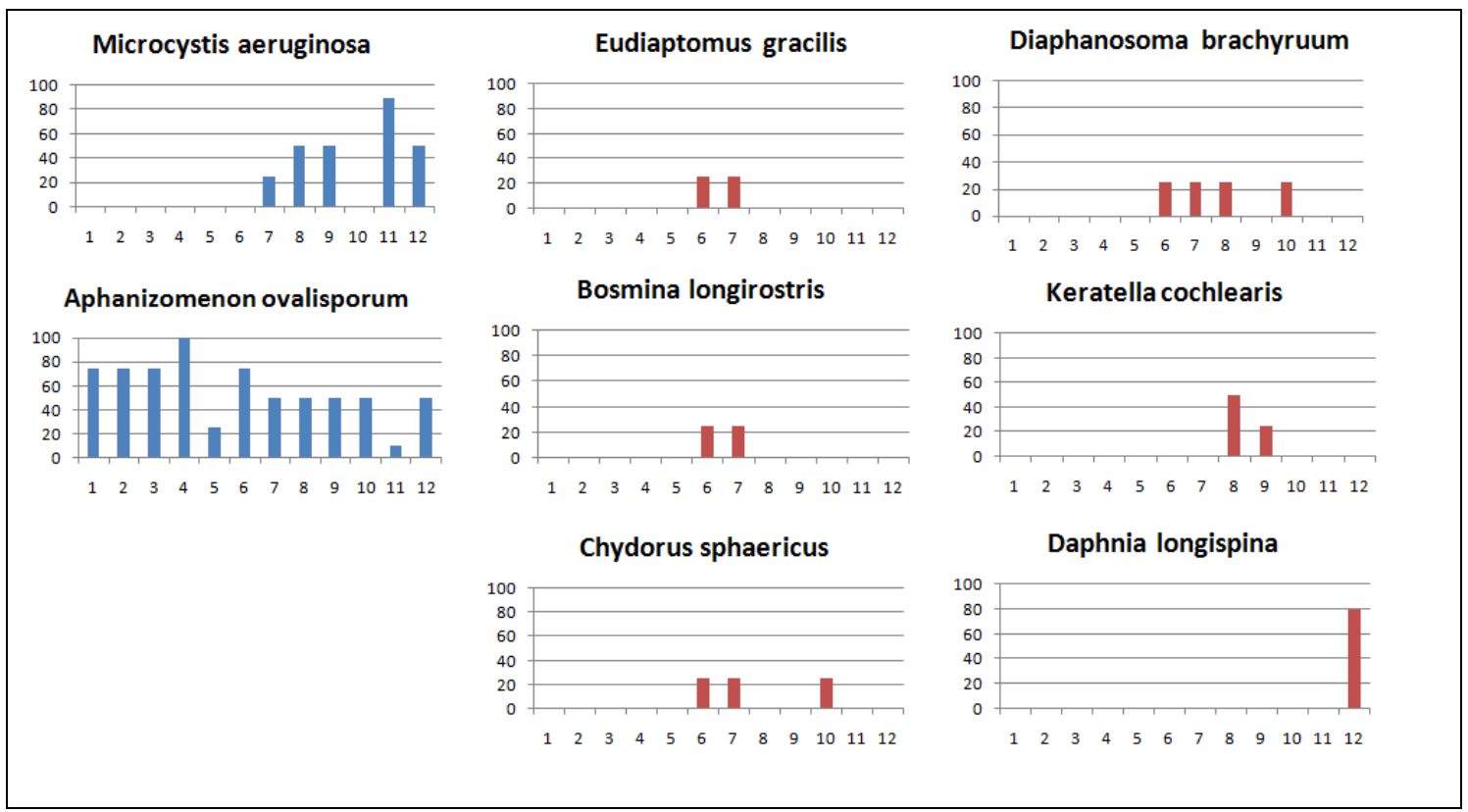

Figure 3. Relative abundance of zooplankton (red histograms) and cyanobacteria species (blue histograms) in percentage during 2016. 


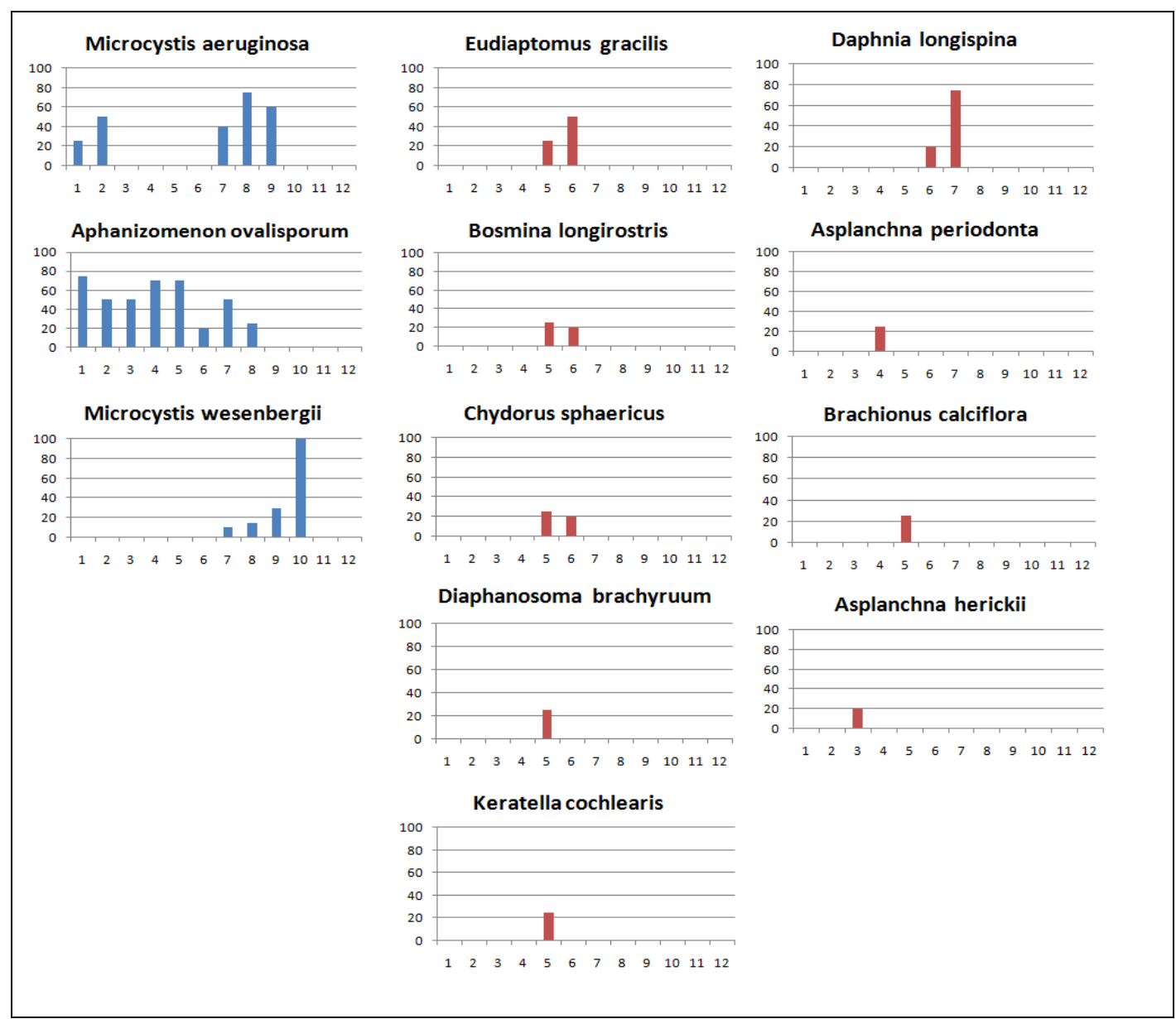

Figure 4. Relative abundance of zooplankton (red histograms) and cyanobacteria species (blue histograms) in percentage during 2017.

Cladoceran biomass was not significantly affected by cyanobacteria, but this may not be an accurate representation on how more specific cladoceran taxa (e.g. Daphnia,Bosmina, etc) were affected by cyanobacteria, because different taxa tend to be affected differently (Fulton and Paerl, 1988; Fulton Rolland S., 1988). Several researchers have found that cyanobacteria morphology was a contributing factor to their effect on zooplankton (Fulton and Paerl, 1988; Tillmanns et al., 2008), for example, zooplankton were found to shorten filament length and even ingest filamentous cyanobacteria. The majority of cyanobacteria found in this study were filamentous (except in the late season in Yankee Hill reservoir), which could limit the influence of cyanobacteria on cladocerans (Tillmanns et al., 2008; Work and Havens, 2003).

Cyanobacteria did not have a significant effect on Daphnia biomass. Alternative food sources may have allowed for the lack of cyanobacteria inhibition, because although cyanobacteria may have made up a majority of total phytoplankton biovolume there may have been enough alternative food sources (diatoms, chlorophytes, and euglenoids) to sustain daphnids (lampert and Sommer, 2007). Certain daphnid species 
subjected to high densities of cyanobacteria in the past may adapt to subsequent high densities of cyanobacteria and become less hindered by these situations, which could help explain the non-significant effect of cyanobacteria on daphnids in the present study. Demott et al. (2001) found that the smaller daphnid, D.cucullata, did better in experiments with cyanobacteria than larger daphnids, such as D.galeata and D. magna. The daphnid species that dominated Nebraska reservoirs in this study were D. ambigua, which are similar in size to D. cucullata. This may account forthe significant interaction effect of time and cyanobacteria percentages on the daphnid group seen in the Nebraska reservoirs, and why cyanobacteria alone did not have a significant effect (DeMott William et al., 2001).

\section{Bosmina biomass was significantly affected by cyanobacteria relative percentage.}

Cyanobacteria percentage had a positive effect on Bosmina, suggesting that this genus may tolerate cyanobacteria better than other cladocerans. B. meridionalis was able to survive and reproduce during Anabaena blooms in Lake Rotongaio, which supports the present findings.

The other cladoceran group (Ceriopdaphnia, Diaphanosoma, Alonella) was significantly affected by the interaction of time and cyanobacteria percentage. Lampert (1982) found that smaller species such as, Ceriodaphnia and Bosmina, were less affected by cyanobacteria than other larger cladocerans. Fulton and Paerl (1988) found that Diaphanosoma clearance rates were affected very little by colonial Microcystis. These observations support our findings that cyanobacteria alone did not have a significant effect on other cladoceran groups and may be the reason why biomass increased later in the season.

Copepods as a group were not significantly affected by cyanobacteria. When divided into finer taxonomic grouping (cyclopoid, calanoid, and nauplii), cyclopoid and calanoid copepods were not significantly affected by cyanobacteria. This is consistent with the findings of other researchers (DeMott William et al., 2001; Fulton and Paerl, 1988; Lampert, 1981). Nauplii had a significant positive response to cyanobacteria. Cyclopoid nauplii were the most selective feeders, and in a feeding experiment, chose flavored spheres over cyanobacteria. This suggests that nauplii could be better at finding and choosing alterative food sources when cyanobacteria dominate a system, and could explain why they exhibited a positive relationship with cyanobacteria in this study (DeMott William and Charles, 1982).

Cyanobacteria did not significantly affect rotifer biomass. Bouvy et al. (2001) observed increasing amounts of rotifers with cyanobacteria increases and subsequent decreases when cyanobacteria declined (Bouvy et al., 2001). In another case, Tillmanns et al. (2008) found rotifers had positive growth in the presence of cyanobacteria, albeit the rate at which growth occurred was lower. Fulton and Paerl (1988) found that clearance rates for rotifers were affected little when fed high densities of Microcystis. 
These observations could explain in part why rotifer biomass was not greatly affected by cyanobacteria in the present study (Fulton and Paerl, 1988).

At field and in laboratory studies, growth, reproduction and survival of cladocerans are negatively affected by cyanobacteria populations due to their toxicity, poor nutritional value and the physical interference by large colonies or filaments with feeding. Cladocera exposed to cyanobacteria cells or toxins show different sensitivities depending on species, clones and also Bosmina longirostris dominates the cladoceran community almost throughout the year. This small Cladocera is more resistant to cyanobacteria than Daphnia since it can avoid ingestion of toxic cells more easily and is more tolerant to those ingested (DeMott William and Charles, 1982; Fulton Rolland S., 1988)

\section{Cyprinus carpio}

Cyprinus carpio (common carp) is a widespread species found in various freshwater habitats, including Karaoun dam, feeding on aquatic crustaceans, insects, worms, detritus, algae and cyanobacteria. The cyano-toxicological effects on the common carp are thought to be quite important given its commercial importance as a product of inland fisheries and aquaculture. Planktivorous fish, such as the carp, intentionally ingest cyanobacteria and, in the process, are also exposed to cyanobacterial metabolites through the aquatic food web (Christelle and Patrick, 2009).

Zooplankton consumption of bacteria and cyanobacteria (filamentous and colonial) was extensive in lake. The results indicated that all planktonic taxa, including a wide range of flagellates, ciliates, rotifers, cladocerans and copepods, can graze bacteria and that all macrozooplankton can graze filamentous and colonial cyanobacteria, although diatoms may be preferred (Work and Havens, 2003).

\section{Zooplankton as carp food}

Common carp is mainly omnivorous, even if the proportion of animal prey in the diet is usually above 75\% (Michel and Oberdorff, 1995). While zooplankton represent an important component of the diet for carp larvae and advanced fry, feeding behavior gradually changes as they grow, reflecting their specific feeding habit and food range. A few days after hatching, the fish feed mainly on small zooplankton such as rotifers and copepod nauplii; after a short period, however, they shift to larger organisms such as cladocerans and copepods (Dulic, 2015). This change occurs gradually and depends largely on the size of the fish mouth, which is also correlated with body size.

Zooplankton plays an important role in the life cycle of common carp in fishponds. As in other fish species, carp larvae feed mainly on zooplankton, starting with small organisms (rotifers) and as they grow, they shifting to larger organisms, e.g. copepods and cladocerans. As adults, they are commonly benthic feeders, concentrating principally on zoobenthos (mainly chironomid larvae). However, zooplankton is also an 
important part of the diet, depending on food availability and spatial and temporal variation. Zooplankton is high in protein (above 50\% of dry matter for some groups) and lipids (approximately 10\% of dry matter with a significant proportion of unsaturated fatty acids). Therefore, they provide a high nutritional content, compared to other diets(Anton-Pardo and Adámek, 2015). Appropriate management strategies in fishponds can potentially increase the production of zooplankton, e.g. monitoring zooplankton levels and stocking fish at the appropriate moment, control of environmental variables favoring zooplankton development, and utilizing sustainable fish stocking densities.

Despite extremely high initial microcystin levels Daphnia populations can increase in the absence of fish predation, to the point where they can strongly reduce phytoplankton biomass. Given the ability of these daphnid populations to increase under such conditions, our results suggest that negative relationships between lake productivity or cyanobacterial abundance and the abundance of large daphnids is probably less a function of phytoplankton composition and more likely driven by the increasing abundance of planktivorous fishes with nutrient enrichment (Orlando, 1992).

\section{CONCLUSION}

Lakes and reservoirs throughout the world have suffered from eutrophication and cyanobacterial blooms, and global warming has aggravated this negative development. Cyanobacterial blooms have harmful effects on the zooplankton and alter the composition and biodiversity of both phytoplankton and zooplankton communities. In the present study, the abundance, composition and biodiversity of zooplankton demonstrated a clear response to the spatial variations in cyanobacteria in Lake Karaoun in May-June. Having strongly contributed to the exhaustion of their food resources and being equally submitted to a strong predation from the zooplankton feeding fish such as the carps, the zooplanktonic species decrease gradually till their total disappearance at the beginning of summer of each year.

\section{ACKNOWLEDGEMENT}

This research with done by the support of a project funded by the Lebanese National Council for Scientific Research (CNRS).

\section{REFERENCES}

Anton-Pardo, M., Adámek, Z. 2015. The role of zooplankton as food in carp pond farming: a review. J. Appl. Ichthyol. 31: 7-14. https://doi.org/10.1111/jai.12852

Bouvy, M., Pagano, M., Marc Troussellier. 2001. Effects of a cyanobacterial bloom (Cylindrospermopsis raciborskii) on bacteria and zooplankton communities in Ingazeira reservoir (northeast Brazil) . Aquat. Microb. Ecol. 25: 215-227.

Chorus, I., Bartram, J. 1999. Toxic Cyanobacteria in Water: A guide to their public health consequences, monitoring and management. E \& FN Spon, published on behalf of the World Health Organization, New York.

Christelle, M., Patrick, K. 2009. Effects of microcystins on fish. Environ. Toxicol. 
Chem. 25: 72-86. https://doi.org/10.1897/05-029R.1

Darwish, T., Atallah, T., Fadel, A., 2018. Challenges of soil carbon sequestration in NENA Region. SOIL. 4: 225-235. https://doi.org/10.5194/soil-2017-39

Darwish, T., Fadel, A., 2017. Mapping of soil organic carbon stock in the Arab countries to mitigate land degradation. Arab. J. Geosci. 10. https://doi.org/10.1007/s12517-017-3267-7

DeMott William, R., Charles, K.W., 1982. Competition Among Cladocerans: Nature of the Interaction Between Bosmina and Daphnia. Ecology. 63: 1949-1966. https://doi.org/10.2307/1940132

DeMott William, R., D., G.R., Ellen, V.D., 2001. Daphnia food limitation in three hypereutrophic Dutch lakes: Evidence for exclusion of large-bodied species by interfering filaments of cyanobacteria. Limnol. Oceanogr. 46: 2054-2060. https://doi.org/10.4319/lo.2001.46.8.2054

DeMott William, R., Qing-Xue, Z., W., C.W., 2018. Effects of toxic cyanobacteria and purified toxins on the survival and feeding of a copepod and three species of Daphnia. Limnol. Oceanogr. 36: 1346-1357. https://doi.org/10.4319/lo.1991.36.7.1346

Dulic, Z., 2015. Role and significance of zooplankton in semi-intensive carp production, in: International Conference "aquaculture \& Fishery" - Conference Proceedings.

El Hourany, R., Fadel, A., Gemayel, E., Abboud-Abi Saab, M., Faour, G., 2017. Spatiotemporal variability of the phytoplankton biomass in the Levantine basin between 2002 and 2015 using MODIS products. Oceanologia. 59: 153-165. https://doi.org/http://doi.org/10.1016/j.oceano.2016.12.002

Fadel, A., 2014. Physico-chemical functioning and development of phytoplankton in Karaoun reservoir (Lebanon): application of a hydrodynamic-ecological model. (Doctoral dissertation, Paris Est).

Fadel, A., Atoui, A., Lemaire, B., Vinçon-Leite, B., Slim, K., 2014. Dynamics of the toxin cylindrospermopsin and the cyanobacterium Chrysosporum (Aphanizomenon) ovalisporum in a Mediterranean eutrophic reservoir . Toxins (Basel). 6: 3041-3057.

Fadel, A., Atoui, A., Lemaire, B.J., Vinçon-Leite, B., Slim, K., 2015. Environmental factors associated with phytoplankton succession in a Mediterranean reservoir with a highly fluctuating water level. Environ. Monit. Assess. 187: 633. https://doi.org/10.1007/s10661-015-4852-4

Fadel, A., Faour, G., Slim, K., 2016. Assessment of the trophic state and chlorophyll-a concentrations using Landsat OLI in Karaoun Reservoir, Lebanon. Leb. Sci. J. 17: 130 .

Fadel, A., Lemaire, B.J., Vinçon-Leite, B., Atoui, A., Slim, K., Tassin, B., 2017. On the successful use of a simplified model to simulate the succession of toxic cyanobacteria in a hypereutrophic reservoir with a highly fluctuating water level. Environ. Sci. Pollut. Res. https://doi.org/10.1007/s11356-017-9723-9

Fadel, A., Sharaf, N., Siblini, M., Slim, K., Kobaissi, A., 2019. A simple modelling approach to simulate the effect of different climate scenarios on toxic cyanobacterial bloom in a eutrophic reservoir. Ecohydrol. Hydrobiol. https://doi.org/https://doi.org/10.1016/j.ecohyd.2019.02.005

Fadel, A., Slim, K., 2018. Evaluation of the Physicochemical and Environmental Status 
of Qaraaoun Reservoir, in: Shaban, A., Hamze, M. (Eds.), The Litani River, Lebanon: An Assessment and Current Challenges. Springer, pp. 71-86.

Fulton, R.S., Paerl, H.W., 1988. Effects of the blue-green alga Microcystis aeruginosa on zooplankton competitive relations. Oecologia. 76: 383-389. https://doi.org/10.1007/BF00377033

Fulton Rolland S., I.I.I., 1988. Resistance to blue-green algal toxins by Bosmina longirostris. J. Plankton Res. 10: 771-778.

Gołdyn, R., Kowalczewska-Madura, K., 2008. Interactions between phytoplankton and zooplankton in the hypertrophic Swarzędzkie Lake in western Poland. J. Plankton Res. 30: 33-42. https://doi.org/10.1093/plankt/fbm086

Griffin, S.L., Herzfeld, M., Hamilton, D.P., 2001. Modelling the impact of zooplankton grazing on phytoplankton biomass during a dinoflagellate bloom in the Swan River Estuary, Western Australia. Ecol. Eng. 16: 373-394.

Gumbo, R.J., Ross, G., Cloete, E.T., 2008. Biological control of Microcystis dominated harmful algal blooms. 7: 4765-4773.

Imai, H., Chang, K.H., Nakano, S., 2009. Growth responses of harmful algal species Microcystis (cyanophyceae) under various environmental conditions. In: Obayashi Y, Isobe T, Subramanian A, Suzuki S, Tanabe S (eds) Interdisciplinary Studies on Environmental Chemistry-Environmental Research in As.

Komárek, J., Anagnostidis, K., 2005. Cyanoprokaryota 2 Teil: Oscillatoriales. Büdel, B., Gärtner, G., Krienitz, L. \& Schagerl, M (eds), Süßwasserflora von Mitteleuropa Band 19/2, Spektrum Akademischer Verlag (Elsevier).

Komárek, J., Anagnostidis, K., 1999. Cyanoprokaryota 1 Teil: Chroococcales. Ettl, H., Gärtner, G., Heynig, G.H. \& Mollenhauer, D. (eds), Süßwasserflora von Mitteleuropa Band 19/1, Spektrum Akademischer Verlag.

Lampert, W., 1981. Inhibitory and Toxic Effects of Blue-green Algae on Daphnia. Int. Rev. der gesamten Hydrobiol. und Hydrogr. 66: 285-298. https://doi.org/10.1002/iroh.19810660302

lampert, W., Sommer, U., 2007. Limnoecology, the ecology of lakes and streams. Oxford University Press, New York.

Latour, D., Salencon, M.J., Reyss, J.L., Giraudet, H., 2007. Sedimentary imprint of Microcystis aeruginosa (Cyanobacteria) blooms in Grangent reservoir (Loire, France). J. Phycol. 43: 417-425. https://doi.org/10.1111/j.15298817.2007.00343.x

Mcheik, A., Awad, A., Fadel, A., Mounzer, C., Nasreddine, S., 2018. Effect of Irrigation Water Quality on the Microbial Contamination of Fresh Vegetables in the Bekaa Valley, Lebanon. Am. J. Agric. For. 6: 191-197.

Michel, P., Oberdorff, T., 1995. Feedin habits of fourteen european freshwater fish species. Cybium.

Orlando, S., 1992. Nutrient Enrichment and Grazer Effects on Phytoplankton in Lakes. Ecology. 73: 551-560. https://doi.org/10.2307/1940761

Paerl, H.W., 2008. Climate - blooms like it hot. Science (80-. ). 320: 57-58.

Paerl, H.W., Huisman, J., 2009. Climate change: a catalyst for global expansion of harmful cyanobacterial blooms. Environ. Microbiol. Rep. 1: 27-37. https://doi.org/10.1111/j.1758-2229.2008.00004.x 
Robarts, R.D., Zohary, T., 1987. Temperature effects on photosynthetic capacity, respiration, and growth rates of bloom-forming cyanobacteria. New Zeal. J. Mar. Freshw. Res. 21: 391-399.

Slim, K., 1996. Contribution to the study of the flora of the basin of the Litani basin. Leb. Sci. Res. Report. 1: 65-73.

Slim, K., Fadel, A., Atoui, A., Lemaire, B.J., Vinçon-Leite, B., Tassin, B., 2014. Global warming as a driving factor for cyanobacterial blooms in Lake Karaoun, Lebanon. Desalin. Water Treat. 52: 2094-2101. https://doi.org/10.1080/19443994.2013.822328

Sommer, U., Adrian, R., De Senerpont Domis, L., Elser, J.J., Gaedke, U., Ibelings, B., Jeppesen, E., Lurling, M., Molinero, J.C., Mooij, W.M., van Donk, E., Winder, M., 2012. Beyond the Plankton Ecology Group (PEG) Model: Mechanisms Driving Plankton Succession. Annu. Rev. Ecol. Evol. Syst. 43: 429-448. https://doi.org/doi:10.1146/annurev-ecolsys-110411-160251

Sommer, U., Gliwicz, Z.M., Lampert, W., Duncan, A., 1986. The PEG-model of seasonal succession of planktonic events in freshwater. Arch. fur Hydrobiol. 106: 433-471.

Temsah, M., Tarhini, K., Fadel, A., Slim, K., 2016. Effect of Irrigation with Lake Water Containing Cylindrospermopsin Toxin on Seed Germination and Seedlings Growth of Cucumis Sativus and Lycopersicon Esculatum. Int. J. Sci. Basic Appl. Res. 27: 108-122.

Tillmanns, A.R., Wilson, A.E., Pick, F.R., Sarnelle, O., 2008. Meta-analysis of cyanobacterial effects on zooplankton population growth rate: species-specific responses. Fundam. Appl. Limnol. / Arch. für Hydrobiol. 171: 285-295. https://doi.org/10.1127/1863-9135/2008/0171-0285

Vinçon-Leite, B., Fadel, A., Lemaire, B.J., Bonhomme, C., Li, Y., Le Divecgen, G., Zhang, J., Luo, Y., 2017. Short-term forecasting of cyanobacteria blooms in Yuqiao reservoir, China. La Houille Blanche. 2: 35-44.

Wilson, A.E., Wilson, W.A., Hay, M.E., 2006. Intraspecific Variation in Growth and Morphology of the Bloom-Forming Cyanobacterium Microcystis aeruginosa. Appl. Environ. Microbiol. 72: 7386-7389. https://doi.org/10.1128/aem.00834-06

Work, K.A., Havens, K.E., 2003. Zooplankton grazing on bacteria and cyanobacteria in a eutrophic lake. J. Plankton Res. 25: 1301-1306. https://doi.org/10.1093/plankt/fbg092

Yang, Z., Kong, F., Shi, X., Cao, H., 2006. Morphological Response of \&lt;i\&gt;Microcystis aeruginosa\&lt;/i\&gt; to Grazing by Different Sorts of Zooplankton. Hydrobiologia. 563: 225-230. https://doi.org/10.1007/s10750005-0008-9 